\title{
First Record of Morphological and Molecular Identification of Mealybug Pseudococcus Jackbeardsleyi (Hemiptera: Pseudococcidae) in Costa Rica
}

\author{
Melissa Palma-Jiménez ${ }^{1}$, Mónica Blanco-Meneses ${ }^{2, *}$ \\ ${ }^{1}$ Master Program at the University of Costa Rica, Costa Rica \\ ${ }^{2}$ Molecular Phytopathology Laboratory, CIPROC, Agronomy Department, University of Costa Rica, Costa Rica
}

Copyright $\bigcirc 2016$ by authors, all rights reserved. Authors agree that this article remains permanently open access under the terms of the Creative Commons Attribution License 4.0 International License

\begin{abstract}
Pseudococcus jackbeardsleyi is a native species of the Neotropical region. Currently there is not an updated record of these species of mealybug in Costa Rica. The aim of this study was to analyze female mealybugs from Siquirreña plantation, Siquirres, Province of Limón, describing the morphology of the insect through the traditional technique of light microscopy and also a molecular description by three universal genes (18S ribosomal, E.F-1 $\alpha$ and COXI). The morphological description was made in the Center for Research on Microscopic structures (CIEMic, acronyms in Spanish), UCR on 2012 and the molecular analysis was done in the Molecular Phytopathology Laboratory ending on 2014. According to the obtained results, the insect was described by the presence of the oral rim tubular duct, which was corroborated by the technique of Scanning Electron Microscopy as defining characteristic that differentiates $P$. jackbeardsleyi from $P$. elisae. Likewise through phylogenetic trees from molecular results, it was observed that the species P. jackbeardsleyi reported in the GenBank (NCBI) showed no association with any of the sequences of the study; therefore this research presents the first record of $P$. jackbeardsleyi in Costa Rica.
\end{abstract}

Keywords Anatomy, Atlantic Region, Musa AAA, Phylogeny

\section{Introduction}

Mealybugs (Hemiptera: Pseudococcidae) are small insects, typically less than $5 \mathrm{~mm}$ long; are plant-sucking insects which form the second largest family group within the scale insects (Coccoidea) with 2,256 species in 291 genera [12]. Occur world-wide, but are most abundant in the tropics and subtropics [1].

An analysis executed by Downie and Gullan [5], found three major clades of mealybugs which equate to the subfamilies Pseudococcinae, Phenacoccinae and Rhizoecinae. Within Pseudococcinae, the authors recognized the tribes Planococcini, Trabutinini and Pseudococcini (the largest genera of mealybugs are Dysmicoccus, Pseudococcus and Trionymus) [11].

According to Downie and Gullan [5], relationships among many Pseudococcid genus are poorly known and there is no stable higher level classification. Occasionally authors have used informal groupings. Tribal names have been used by some authors but, these groups are not widely used, and often they are equivalent to the subfamily groups of other authors. Hardy and Gullan [11] mention that authors have applied various combinations of names to various ranks, and none is in common use, in part owing to the inadequate definition of groups, in terms of either their generic composition or their diagnostic morphology.

The current taxonomy and classification of mealybugs are based on the morphology of adult females. There is no satisfactory or generally accepted suprageneric classification for mealybugs. There has been much work on the alpha-level taxonomy, amounting to the description of more than 2000 species, but suprageneric relationships remain poorly known [11].

According to Williams and Granara de Willink [29], adult females of species of Pseudococcidae have an extremely heterogeneous morphology. The vast majority can be recognized by having most of the following features: trilocular pores; cerarii, at least on anal lobes; circuli; three-segmented labium with four close-set fleshy, apicoventral setae on each side of the terminal segment; four hygroreceptors on the antennae, one on the pedicel, one on segment IV, and two on the terminal segment; one pair of interflagellar setae; claws without basal denticles; and tubular ducts without vestibule.

Hardy and Gullan [10] explain that particularly the history of the generic name Pseudococcus Westwood is extremely complicated. In 1905, Cockerell erected the tribe 
Pseudococcini within the Coccidae for Pseudococcus Westwood. In 1930, Lobdell was the first to use the family name Pseudococcidae for the mealybugs a practice subsequently followed by all entomologists.

Pseudococcus jackbeardsleyi (Hemitera: Pseudococcidae) is known as mealybug Jack Beardsley; this is a species from the Neotropical region, often in the Caribbean, Central and South America $[6,20,24]$. This mealybug is characterized as polyphagous [25], feeding on about 47 families of economically important crops [1]. Among the most common genus are: Ananas, Cajanus, Capsicum, Carica, Citrus, Cocos, Coffea, Cucumis, Cucurbita, Ficus, Gossypium, Hibiscus, Ipomoea, Litchi, Macadamia, Mangifera, Manihot, Mentha, Morus, Musa, Nephelium, Ocimum, Persea, Phaseolus, Piper, Psidium, Punica, Salvia, Solanum, Tamarindus, Theobroma, Vitis y Zea $[1,20,24]$. It has been most commonly collected from crop as: Solanum tuberosum, Capsicum annuum, Lycopersicum esculentum y Musa spp. [6].

Costa Rica is reported as a country where $P$. jackbeardsleyi has been identified. However there is not an updated record of this kind of mealybug, specifically on commercial plantations $[6,29]$, as it exists in other countries in the Neotropical region, such as in Tamilnadu from India in papaya crops $[15,24]$ and the Marfil Coast from Africa in cocoa crops (N'Guessan et al 2014).

One of the main concerns is the misclassification of this mealybug about on species of "Pseudococcus maritimus Complex" [6]. Gimpel and Miller [6] demonstrated misidentification in the species Pseudococcus elisae regarding to $P$. jackbeardsleyi, information recorded in several articles published before 1996 [1,3,4]. The most important morphological character to differentiate both species is the presence of an oral rim tubular duct nearby the VII segment in the dorsal area of $P$. jackbeardsleyi, which was previously described to P. elisae by Beardsley [2]. Another morphological character to differentiate them is the number of oral rim tubular ducts in the tergal abdomen, to $P$. elisae they are accounted for up to 14 and to $P$. jackbeardsleyi there are more than $14[6,17,29]$.

Due to the difficulty of morphological description, it requires a correct analysis in female adult mealybug; and the molecular markers are presented with a reliable tool to characterize species efficiently [14].

The characterization of $P$. jackbeardsleyi by anatomical description of the insect with a molecular analysis supports the rapid and accurate identification of the pest. The molecular identification in this effect is efficient and reliable because it is not limited by life stage and genus [15].

This investigation makes evident the presence of $P$. jackbeardsleyi provided in banana plantations located in Costa Rica, using morphological and molecular methods for the identification.

\section{Materials and Methods}

\subsection{Sample Collections}

Female mealybugs from Siquirreña farm (Siq) in Siquirres, Limón province from Costa Rica, were collected in 2012. An average of 20 mealybugs in $1.5 \mathrm{~mL}$ Eppendorf tube with $95 \%$ ethanol was collected.

\subsection{Place of Study}

The morphological analysis was performed at the Center for Research on Microscopic structures (CIEMic, acronyms in Spanish) in 2012 and the molecular analysis was performed in the Molecular Phytopathology Laboratory at the Center for Research in Crop Protection CIPROC (acronyms in spanish) of Costa Rica, ending in 2014, both at the University of Costa Rica, San Pedro de Montes de Oca.

\subsection{Observation under the Light Microscope}

Ten insects were processed. The protocol described by Williams and Granara de Willink [29] was followed.

To identify the translucent structures, the insects were examined with light microscopy equipment, using increases $4 \mathrm{x}, 10 \mathrm{x}, 20 \mathrm{x}$ and 40x and photographed with the inverted model IX51, Olympus Optical Co., Japan microscope.

The analyzed structures by light microscopy corresponded to the following: body shape, number of segments of the antenna, translucent pores around the eyes, mouthparts and stylets, description of metacoxas (posterior legs) and presence of translucent pores, description of the circulus, ostioles, oral rim tubular ducts, anal lobe bar and cerarii.

\subsection{Analysis Scanning Electron Microscope}

The protocol by [21] was followed.

\subsection{Amplification of Genomic DNA}

The protocol by Murray and Thompson [18] was used. One insect was used for each DNA extraction. The genomic DNA extracted was amplified by PCR. Initially, five pairs of primers were used to observe which ones had polymorphism of interest in a sub-sample of DNA ribosomal, nuclear, and mitochondrial of mealybugs. At the end of testing three pairs of these primers were selected (Table 1).

For all PCR reactions in a $1 \mathrm{x}(\mathrm{ul})$ solution it was used: $13.5 \mu \mathrm{L}$ of $\mathrm{H}_{2} \mathrm{O}, 2.5 \mu \mathrm{L}$ of buffer (10x), $2 \mu \mathrm{L}$ of dNTPs $(2 \mathrm{mM}), 1.5 \mu \mathrm{L}$ each for each pair primer $(10 \mu \mathrm{M}), 0.3 \mu \mathrm{L}$ of Dream Taq polymerase $(5 / \mu \mathrm{L})$ to $23 \mu \mathrm{L}$ of master mix per eppendorf tube, all reagents Fermentas, and finally adding $2 \mu \mathrm{L}$ of DNA $(10 \mu \mathrm{g} / \mathrm{mL})$. The amplification reaction was performed using the following thermal profile: an initial predenaturation at $94^{\circ} \mathrm{C}$ for $4 \mathrm{~min}$, followed by 30 cycles of 
denaturation at $94^{\circ} \mathrm{C}$ for $1 \mathrm{~min}$, annealing for $1 \mathrm{~min}$ at the temperature specified in each primer pair (Table 1), chain elongation at $72^{\circ} \mathrm{C}$ for $1 \mathrm{~min}$ and $30 \mathrm{~s}$, followed by a final extension at $72^{\circ} \mathrm{C}$ for $4 \mathrm{~min}$. The reactions and cycling conditions were carried out in an automated thermocycler Eppendorf Mastercycler pro.

The PCR product was separated on an agarose gel (agar + $0.5 \mathrm{X}$ TBE buffer). The PCR product was digested with Exonuclease I (ExoI) from Fermentas. Sequencing was performed on the purified PCR product at a concentration of $50 \mathrm{ng} / \mu \mathrm{L}$ by the company Macrogen, Inc. (South Korea).

\subsection{Sequence Alignment and Phylogenetic Analysis}

Sequences in both directions were obtained. The quality of the sequences was confirmed in a bidirectional alignment and by comparison of the chromatograms using the BioEdit program v7.0.5 [9]. To determine the species according to the result of sequencing, the GenBank was used [19,23]. All sequences were aligned with the ClustalW program version $1.60[29]$.

For the phylogenetic analysis, sequences were included from species previously reported by GenBank for all three genes studied, such as: Dysmicoccus neobrevipes, Hypogeococcus pungen, Plotococcus eugeniae, $P$. jackbeardsleyi, P. longispinus, P. maritimus and P. viburni. Balanococcus diminutus and Balanococcus takahashii were used to establish the outgroups. The individual origin was verified according to the host plant and the country (Table 2). The analysis of phylogenetic trees was performed using the program MEGA version 5.0 (Molecular Evolutionary Genetic Analysis) [26]. The random parameter of 2000 replications was used to search for phylogenetics trees and Maximum likelihood method for the three genes presented the best groupings between the species analyzed.

Table 1. Primers information used for PCR amplification from: 18 S ribosomal region, nuclear elongation factor $1 \alpha(E F-1 \alpha)$ and mitochondrial cytochrome c oxidase subunit I (COXI).

\begin{tabular}{|c|c|c|c|c|c|}
\hline Gene & Primers & Primer sequence & PCR conditions & $\begin{array}{l}\text { Amplicon average } \\
\text { size (bp) }\end{array}$ & Primer source \\
\hline $18 \mathrm{~S}$ & $\begin{array}{l}18 \mathrm{~S}-2880 \\
18 \mathrm{~S}-\mathrm{B}\end{array}$ & $\begin{array}{l}\text { CTGGTTGATCCTGCCAGTAG } \\
\text { CCGCGGCTGCTGGCACCAGA }\end{array}$ & $\begin{array}{l}94^{\circ} \mathrm{C}, 4 \mathrm{~min} ; 30 \text { ciclos de } \\
94^{\circ} \mathrm{C} 1 \mathrm{~min}, 67^{\circ} \mathrm{C} 1 \mathrm{~min}, 72^{\circ} \mathrm{C} \\
1 \mathrm{~min}, 30 \mathrm{~s} ; 72^{\circ} \mathrm{C} 4 \mathrm{~min}\end{array}$ & 630 & {$[5,14]$} \\
\hline $\begin{array}{l}\text { E.F-1 } 1 \alpha \\
5^{\prime}\end{array}$ & $\begin{array}{l}\text { EF-1_M51.9 } \\
\text { EF-1_rcM53-2 }\end{array}$ & $\begin{array}{l}\text { CACATYAACATTGTCGTSATYGG } \\
\text { CTTGATGAAATCYCTGTGTCC }\end{array}$ & $\begin{array}{c}94^{\circ} \mathrm{C}, 4 \mathrm{~min} ; 30 \text { ciclos } \\
\text { de } 94^{\circ} \mathrm{C} 1 \mathrm{~min}, 62^{\circ} \mathrm{C} 1 \mathrm{~min} \\
72^{\circ} \mathrm{C} 1 \mathrm{~min}, 30 \mathrm{~s} ; 72^{\circ} \mathrm{C} 4 \mathrm{~min}\end{array}$ & 439 & {$[5]$} \\
\hline COXI & $\begin{array}{l}\text { C1-J-2183 } \\
\text { C1-N-2568 }\end{array}$ & $\begin{array}{l}\text { CAACATTTATTTTGATTTTTTGG } \\
\text { GCWACWACRTAATAKGTATCATG }\end{array}$ & $\begin{array}{c}94^{\circ} \mathrm{C}, 4 \mathrm{~min} ; 30 \text { ciclos } \\
\text { de } 94^{\circ} \mathrm{C} 1 \mathrm{~min}, 45^{\circ} \mathrm{C} 1 \mathrm{~min}, \\
72^{\circ} \mathrm{C} 1 \mathrm{~min}, 30 \mathrm{~s} ; 72^{\circ} \mathrm{C} 4 \mathrm{~min} \\
\end{array}$ & 385 & [14] \\
\hline
\end{tabular}

Table 2. GenBank information used for the phylogenetic trees construction: Species, host plant, origin country and GenBank accession number.

\begin{tabular}{|c|c|c|c|c|c|}
\hline \multirow{2}{*}{ Species } & \multirow{2}{*}{ Host Plant } & \multirow{2}{*}{ Origin Country } & \multicolumn{3}{|c|}{ GenBank accession number } \\
\hline & & & $18 \mathrm{~S}$ ribosomal & E.F- $1 \alpha$ & COXI \\
\hline Dysmicoccus neobrevipes & $*$ & China & JF965400.1 & - & - \\
\hline D. neobrevipes & $*$ & USA & U20429.1 & - & - \\
\hline P. jackbeardsleyi & $*$ & Taiwan & KJ145237.1 & - & - \\
\hline Pseudocuccus viburni & $*$ & Suoth África & JQ651125.1 & - & - \\
\hline Balanococcus diminutus** & Phormium tenax & $\begin{array}{l}\text { USA: Watsonville, } \\
\text { CA. }\end{array}$ & AY426069.1 & - & - \\
\hline Dysmicoccus sp. & Lechea sessiliflora & USA: Florida & - & AY427240.1 & - \\
\hline P. jackbeardsleyi & $*$ & USA & - & EU188562.1 & - \\
\hline Pseudocuccus maritimus & Vitis vinifera & USA: Witstrand & - & AY427217.1 & - \\
\hline P. elisae & Musa sp. & Costa Rica & - & KP402191.1 & - \\
\hline Balanococcus diminutus** & Phormium tenax & $\begin{array}{c}\text { USA: Watsonville, } \\
\text { CA. }\end{array}$ & - & AY427250.1 & - \\
\hline Plotococcus engeniae & Eugenia sp. & USA: Tavernier & - & AY427258.1 & - \\
\hline P. viburni & $*$ & Spain & - & - & JF714166.1 \\
\hline Pseudocuccus longispinus & $*$ & Spain & - & - & JF714161.1 \\
\hline P. longispinus & Musa sp. & Philippines & - & - & KP402196.1 \\
\hline P. jackbeardsleyi & $*$ & South Korea & - & - & HQ179904.1 \\
\hline P. jackbeardsleyi & $*$ & India & - & - & KC119455.1 \\
\hline P. elisae & Musa sp. & Costa Rica & - & - & KP402197.1 \\
\hline Balanococcus takahashii** & $*$ & South Korea & - & - & HM474094.1 \\
\hline
\end{tabular}

\footnotetext{
* No reports. ** Out group.
} 


\section{Results}

\subsection{Morphological Characterization}

For the morphological characterization the key established by Gimpel and Miller [6] was used, which is currently accepted by other authors for this species [14, N'Guessan et al., 2014]. It is also the key used by the Phytosanitary Service of the United States [17]. The present study identified the following: body elongated oval-shaped with 17 pairs of cerarii (Figure 1. A); antenna of eight segments (Figure 1. B); translucent pores in the femur and tibia, and the nail lack of the denticle (Figure 1.C); oral rim tubular duct in the head of the insect, specifically adjacent to cerarii C17 (Figure 1. D); cerarii $\mathrm{C} 17$ has three conical setae (Figure 1. D); oval circulus located between the segments III and IV (Figure 1. E); three stylet in the mouthparts (Figure 1. F) and nine discoidal pores in the edge of the eye with a slightly sclerotic rim (Figure 1. G).

Anal lobe without anal bar (Figure 2. A); two conical setae in the cerarii of anal lobe cerarius and $\mathrm{C} 2$ (Figure 2. A and $\mathrm{B}$, respectively); oral rim tubular duct located nearby the segment VII, this feature was documented by light microscopy (Figure 2. A) and scanning electron microscopy, this last technique showed the ultrastructure clearly (Figure 2. B and C).

\subsection{Molecular Analysis}

Representative sequences were obtained for $18 \mathrm{~S}, \mathrm{EF}-1 \alpha$ $5^{\prime}$ and COI regions. To perform the analysis the closest species to the only hits found in GenBank were used (Table 2). Also, new sequences were reported to GenBank, deposited under the accession numbers: KT956119, KT956120 and KT956121.

None of the PCR products showed evidence of divergent sequences (ignoring small differences suggestive of heterozygosity or PCR/sequencing artefacts). Maximum likelihood (ML) analyses were calculated from the number of differences haplotypes for each phylogenetic tree (Figures 3, 4 and 5). ML showed a monophyletic $P$. jackbeardsleyi and found support of a heterogeneous group of species, and does not conform to any of the current views of mealybug relationships for all phylogenetic tree calculated.

The 18S ribosomal gene was unrepresentative. According to the Blast tool results, these showed a high percentage of similarity between different species of the genus Pseudococcus and Dysmicoccus (data not shown). ML phylogenetic tree calculated from the number of differences between $18 \mathrm{~S}$ ribosomal haplotypes showed a clade of $P$. jackbearsleyi from Costa Rica 1, 2 and 3 with a $74 \%$ of similarity between them, related at the same time with the species D. neobrevipes (JF965400) from China (U20429) and USA. Adjacent to this clade is P. viburni (JQ651125.1) from South Africa with $81 \%$ bootstrap. Besides, not grouped with neither of the taxa of the study is the species $P$. jackbearsleyi (KJ145237.1) as the only accession comes from Taiwan. Balanococcus diminutus (AY426069.1) was used as outgroup (Figure 3).

In EF-1 $\alpha 5^{\prime}$ datasets, ML phylogenetic tree calculated from the number of differences between the haplotypes, showed the greatest support for the group of $P$. jackbeardsleyi species, one of these groupings with P. elisae (KP402191.1) from Costa Rica, all shared a bootstrap of 100\% (Figure 4). The next closest species: Dysmicoccus sp. (AY427240.1), P. maritimus (AY427217.1), Plotococcus eugeniae (AY427258.1) and P. jackbearsleyi (EU188562.1), all from USA, showed a low bootstrap support. Balanococcus diminutus (AY427250.1) was used as outgroup.

According to ML phylogenetic tree calculated from the number of differences between mitochondrial (COXI) haplotypes, the results reported high support of $85 \%$ bootstrap for the P. jackbearsleyi and P. elisae (KP402197.1) taxa, both from Costa Rica; these species shared a strong support (100\% bootstrap) with P. longispinus (JF1461.1) from Spain, P. longispinus (KP402196.1) from Philippines and P. viburni (JF714166) from Spain. Being that $P$. jackbearsleyi (KC119455.1) from India shared a boostrap of $54 \%$ according to last clade. P. jackbearsleyi (HQ179904.1) from South Africa fell outside the clade, in unsupported relationships with other taxa. Balanococcus takahashii (HM474094.1) was used as outgroup (Figure 5).

Placement among the Genbank species and the $P$. jackbeardsleyi results is explicable only by homoplasy and/or long-branch attraction in these divergent sequences. 

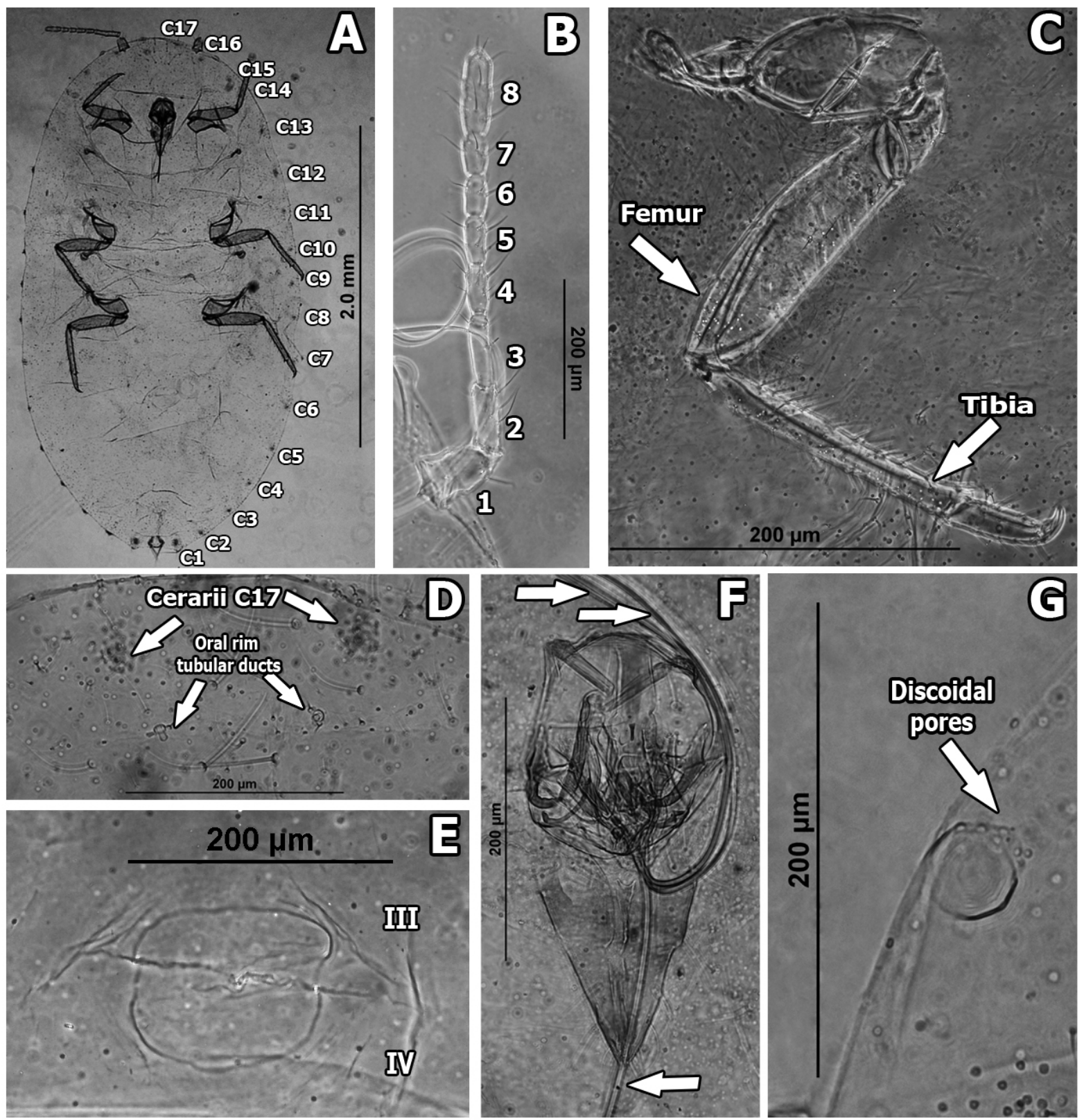

Figure 1. Morphological characters to identify the mealybug Pseudococcus jacksbearlsleyi from banana crop from Siquirreña Farm, Atlantic area, Costa Rica, 2012. Images captured by light microscopy. A. Body elongated oval-shaped. B. Antenna with eight segments. C. Translucent pores in the femur and tibia of the metacoxa. D. Oral rim tubular duct associated to cerarii C17. E. Dividing line circulus in the segments III and IV. F. Mouthparts with three stylets. G. Nine discoidal pores in the edge of the eye. 

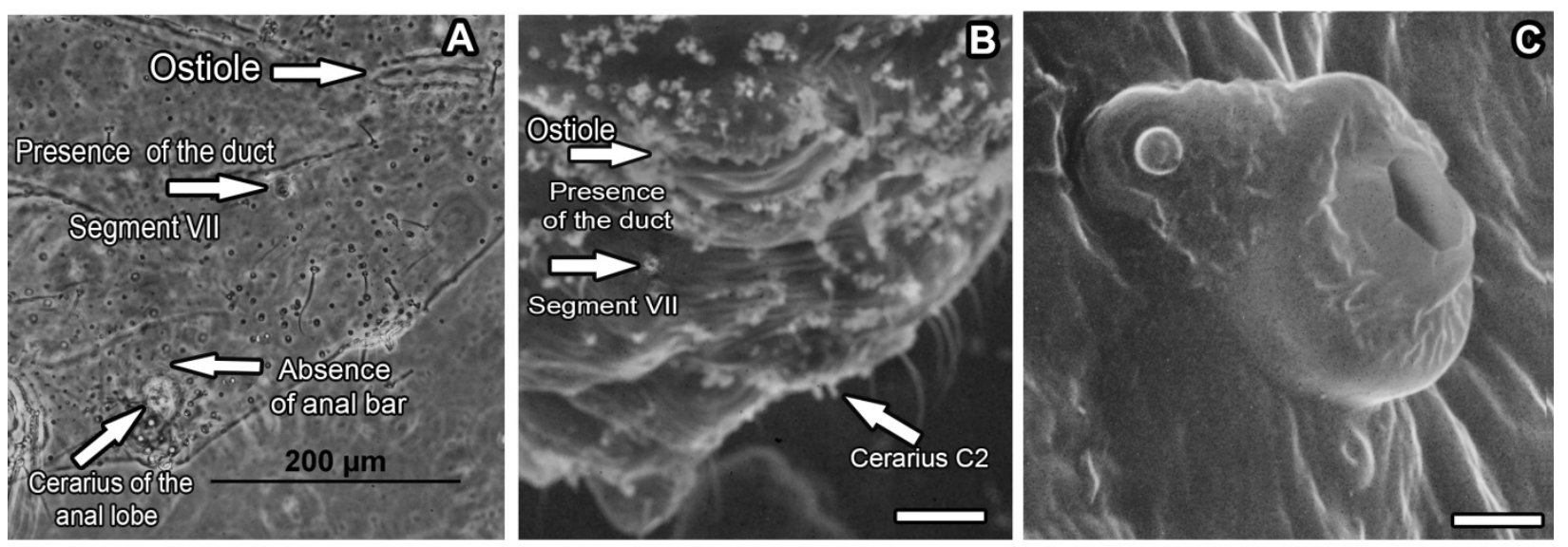

Figure 2. Oral rim tubular duct nearby the segment VII, next to ostiole, to identify the mealybug Pseudococcus jacksbearlsleyi from banana crop from Siquirreña Farm, Atlantic area, Costa Rica, 2012. A. Through light microscopy technique, the lack of anal bar in the anal lobe cerarii was observed B. By scanning electron microscopy technique the presence of the oral rim tubular duct nearby the segment VII was checked. C. Oral rim tubular duct captured by scanning electron microscopy. Scale: $36,4 \mu \mathrm{m}(\mathrm{B}) ; 0,92 \mu \mathrm{m}(\mathrm{C})$.

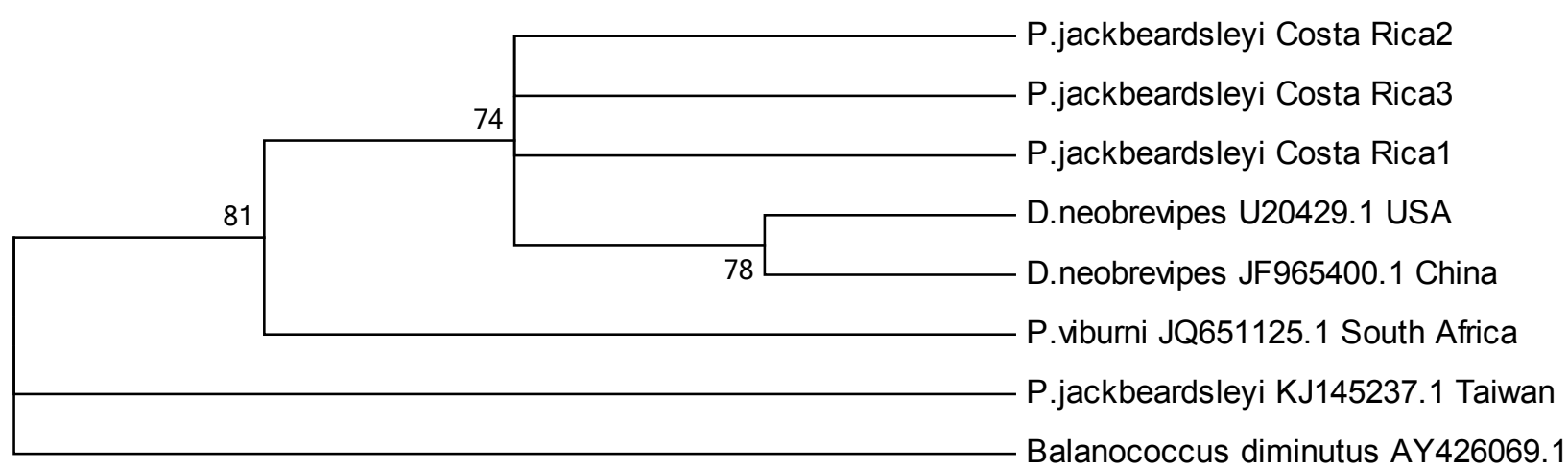

Figure 3. Maximum likelihood phylogenetic tree calculated from the number of differences between $18 \mathrm{~S}$ ribosomal haplotypes. Bootstrap values (2000 replications) are displayed in each node. Balanococcus diminutus (AY426069.1) was used as outgroup.

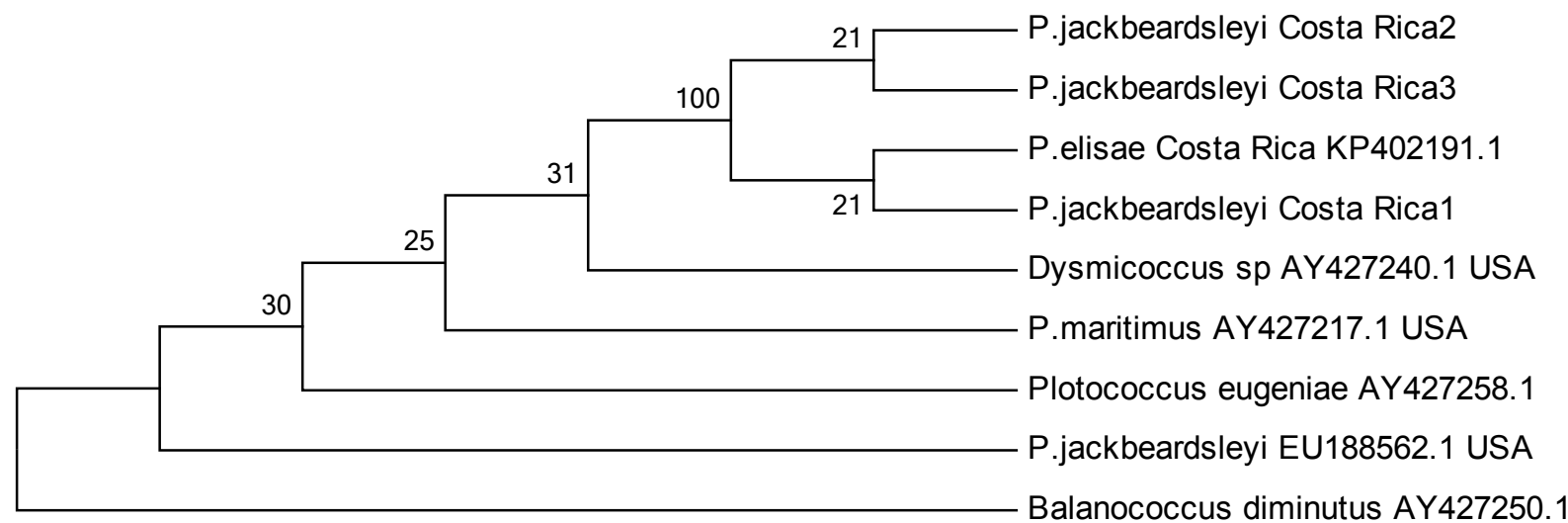

Figure 4. Maximum likelihood phylogenetic tree calculated from the number of differences between elongation factor (E.F-1 $\left.\alpha 5^{\prime}\right)$ haplotypes. Bootstrap values (2000 replications) are displayed in each node. Balanococcus diminutus (AY427250.1) was used as outgroup. 


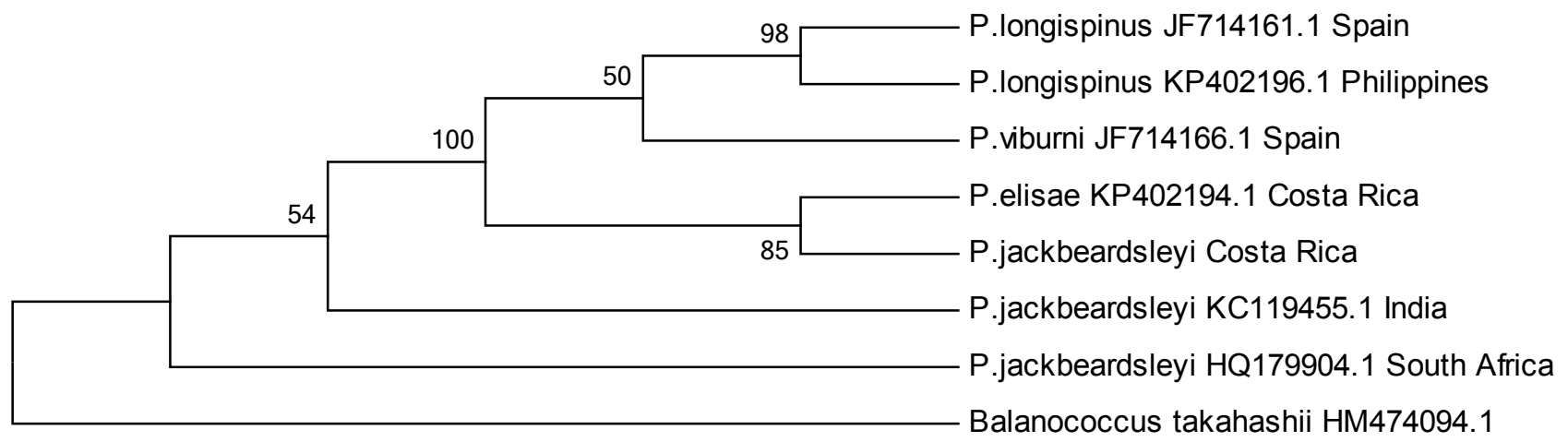

Figure 5. Maximum likelihood phylogenetic tree calculated from the number of differences between mitochondrial (COXI) haplotypes. Bootstrap values (2000 replications) are displayed in each node. Balanococcus takahashii (HM474094.1) was used as outgroup.

\section{Discussion}

When comparing the results from morphological analysis of specimens identified as $P$. jackbeardsleyi, regarding molecular data page from the GenBank, [19], no direct agreement was made in any of the studied genes. According to the submitted GenBank accessions, the articles that mention this species are not published yet to compare the morphological and molecular characters together from other countries (GenBank, 2015). Even in some morphological description, there is no evidence of molecular data [25]. Several authors have mentioned the problem that the unique identification by morphological characters of mealybug can present $[13,16]$. For mealybugs, homoplasy is problematic in these morphological characters, as it is in molecular characters [5]. This is explained by characters shared by a set of species but not present in their common ancestor.

One of the tribes of the Pseudococcidae family discussed by Downie and Gullan [5], the Pseudococcini, is not easy to distinguish morphologically. One of the first characters to distinguish in adult females of species in this group is in having 16-17 pairs of cerarii with auxiliary setae. They mention that the most egregious example may be Pseudococcus genus, represented in their study by six species, of which four were involved in a sister relationship with a different genus, the same is described by Hardy et al. [11]. Something that could explains the results in this investigation.

Gimpel and Miller [6] explain that species Pseudococcus genus, from Pseudococcini tribe, have been confused by the relationship between the morphological characters. They mention that there is a similarity in the systematically of mealybug. In the case of $P$. jackbeardsleyi, this has been confused with the species $P$. elisae to share morphological features such as: 17 pairs of cerarii in the tergal edge of the body, the cerarii $\mathrm{C} 17$ show three conical setae and the anal lobe cerarii two conical setae; presence of two oral rim tubular ducts in the head adjacent to $\mathrm{C} 17$; presence of around nine discoidal pores in the edge of the eye; eight segments in the antenna; translucent pores usually restricted to the femur and tibia of metacoxas; circulus between the segments III and IV; absence of anal bar in the anal lobes; presence of two pairs of ostioles surrounded by trilocular pores [22]. The main difference is the presence of the oral rim tubular duct in segment VII of the sternal abdomen of $P$. jackbeardsleyi; besides, presenting a range of 14-27 oral rim tubular duct in the tergal abdomen and the species having as maximum 14 of these ducts $[6,17,25,29]$.

Other species of Pseudococcus genus, that have been confused by the relationship between morphological characters and are reported within COXI gene results of this study, correspond to $P$. maritimus and $P$. viburni. $P$. maritimus which are characterized by the presence of an oral rim tubular duct between the cerarii 15 and 16, and abundance of oral rim tubular ducts in the abdomen (19 to 35), features that differentiate it from $P$. viburni by be absents; meanwhile $P$. jackbeardsleyi lacks of the oral rim tubular duct between the cerarii 15 and 16 and has a lower number of oral rim tubular ducts in the abdomen (14-27). Also the number of discoidal pores in the edge of the eye to $P$. jackbeardsleyi is greater than seven, regarding previous species, which have from one to three of these pores $[6,17,29]$. According to these features, it is not possible to relate the previous mealybugs with the characters observed in the present study.

In the case of genus mealybugs Dysmicoccus spp., general characteristics as: body shape of globular type, absence of oral rim tubular ducts and more than two conical setae in the adjoining cerarii of the anal lobe, defer to be considered in the description of mealybugs of the present study $[8,17]$. The tested insects have a shaped body elongated oval type, oral rim tubular ducts, cerarii of the anal lobe and the adjacent cerarii $(\mathrm{C} 2)$ have two conical setae.

The species $H$. pungens, which was observed in the blast analysis of the gene COXI, was removed from the tree. It was placed in a derived position as Pseudococcus species. It is very different morphologically. Among the characteristics that distinguish this species are mentioned: the presence of three circles in the region of sternal abdomen of the insect, absence of trilocular pores, numerous multilocular pores in the sternal and tergal area of the insect. While $P$. jackbeardsleyi presents only a circle in the sternal abdomen, 
also it has trilocular pores around the body and numerous multilocular pores restricted to the sternal region of the abdomen [29]. This is why the species $H$. pungens could not be related to the mealybug of this investigation. Other reason, $H$. pungens belong to Tributini tribe and P. jackberdsleyi to Pseudococcini tribe.

The unique identification by morphological characters or only molecular markers can induce errors. Identity percentages of the results from species in GenBank are considered low $(61 \%$ for the $18 \mathrm{~S}, 65 \%$ for E.F and $69 \%$ for COXI), because the number of bases that differentiate them is very high. According to these percentages, the reported as first result in coverage of the sequence and genetic identity for the genes of the study corresponded to the species Dysmicoccus neobrevipes (18S gene), Pseudococcus maritimus (E.F-1 $\alpha$ 5' gene), Pseudococcus viburni (gen COXI). For the species $P$. jackbeardsleyi, the unique report present for the 18S gene was executed in 2014 from Taiwan, for the E.F-1 $\alpha$ gene the only report made was reported in 2008 from USA and in the case of COXI gene, the nearest accession was reported in 2013 from India [19]. The apparently weak relationships between mealybug phylogeny are striking [11]. The mealybug phylogeny reconstructed here is supported by ML analysis with bootstrap support.

EF-1 $\alpha$ 5' gene looks to be prone to confounding from the presence of paralogous copies [5]. However in our EF-1 $\alpha$ datasets the paralogy was not a problem. In this study the EF-1 $\alpha$ ' consensus was resolved but lacked bootstrap support in the root nodes. The evidence that our results are not affected by paralogy, is the corroboration from other genes.

Molecular characters may have greater power to uncover relationships under these circumstances, but the current study shows that molecular data may be no the answer for decode Pseudococcid relationships, just like Downie and Gullan [5] explain. None of the single gene analyses led to a set of strongly supported relationships which would allow confidence in inferring phylogeny across the analyzed species.

The importance of sampling more than one gene has been indicated $[5,7,11]$. It is expected that the results from different regions of the genome are consistent; however, considering the evolutionary rates of the genes, as well as differences in recombination, it should not be surprising that the results of the different regions of the genome are often inconsistent. That said, one wonders what level of confidence placed in a system based on a single genome fragment analysis is [5].

\section{Conclusions}

After comparing the morphological features of the insect and the results of the species from Genbank, the specimens of the study have not been reported yet from Costa Rica as $P$. jackbeardsleyi in bananas, which was morphologically classified in this study according to key used by the
Phytosanitary Service of Costa Rica and Phytosanitary Service of the United States. This could be the first formal report about the establishment of $P$. jackbeardsleyi in Musa sp. plantations in Costa Rica. However, the relationships of the mealybugs are open to question and needs further study. There are still some doubts about these relationships. In this research the mealybug $P$. jackbeardsleyi was identified by molecular methods as a separated species of others $P$. jackbeardsleyi species from different countries. It should be important to considerate relationships of the mealybugs based on adult male morphology, even the geography or to host plant taxa. Even Thao et al. [27] mention that mealybug microbial ecology appears strongly correlated with phylogeny, and within the Pseudococcinae, there is a clear sequence of infection by $\beta$-Proteobacteria primary endosymbionts. As Downie and Gullan [5] mention, a number of species are left in ambiguous positions, which will only be resolved by the inclusion of further taxa and, ideally, also additional molecular data.

\section{Acknowledgements}

We are grateful to MSc. César Guillén from CORBANA, for providing the mealybugs collection used in this study. We thank Ing. Carlos Sanabria from SFE, by the corroboration of morphological characterization. We also thank all CIEMic staff and the Molecular Phytopathology Laboratory for the equipment availability. This research was supported by the Vice-Rectorate of Research at the University of Costa Rica by funding the project code: 813-B1-273 and scholarship code: 810-B2-232.

\section{REFERENCES}

[1] A Data Base of the Scale Insects of the World. United States, Israel and Canada Agricultural Research. [27 Jun 2013]. Online available from:http://www.sel.barc.usda.gov/scalenet /scalenet.htm.

[2] J.W. Beardsley. Taxonomic notes on Pseudococcus elisae Borchsenius, a mealybug new to the Hawaiian fauna (Homoptera: Pseudococcidae), Proceedings of the Hawaiian Entomological Society, Vol.26, 31-34, 1986.

[3] CABI. Pseudococcus elisae (banana mealybug). In: Invasive Species Compendium. Wallingford, UK: CAB International. [07 Set 2013]. Online available from: www.cabi.org/isc

[4] Catalogue of Life. Pseudococcus jackbeardsleyi, ScaleNet: Systematic Database of the Scale Insects of the World in the Catalogue of Life in The Catalogue of Life Partnership. [28 Dic 2013]. Online available from: http://www.gbif.org/speci es/119538008

[5] D.A. Downie and P.J. Gullan. Phylogenetic analysis of mealybugs (Hemiptera: Cocoidea: Pseudococcidae) based on DNA sequences from three nuclear genes, and a review of the higher classification, Systematic Entomology, Vol.29, 238- 
$259,2004$.

[6] W.F. Gimpel and D.R. Miller. Systematic analysis of the mealybugs in the Pseudococcus maritimus complex (Homoptera: Pseudococcidae), Contributions on Entomology International, Vol.2, No.1, 137-163, 1996.

[7] P.J. Gullan and L.G. Cook. Phylogeny and higher classification of the sacel insects. (Hemiptera: sternorrhyncha: Coccoidea), Zootaxa Vol.1668, 413-425, 2007.

[8] M.C. Granara de Willink. Dysmicoccus from the Neotropical Region (Hemiptera: Pseudococcidae), Revista de la Sociedad Entomológica Argentina, Vol.68, No.2, 11-95, 2009.

[9] T.A. Hall. BioEdit: A user-friendly biological sequence alignment editor and analysis program for Windows 95/98/NT. Nucleic Acids Symposium Series, Vol. 41, 95-98, 1999.

[10] N.B. Hardy and P.J. Gullan. PSEUDOCOCCINI Cockerell, 1905 (Insecta, Hemiptera): proposed precedence over SPHAEROCOCCINI Cockerell, 1899. Bulletin of Zoological Nomenclature, Vol.65, 24-26, 2008.

[11] N.B. Hardy, P.J. Gullan and C.J. Hodgson. A subfamily-level classification of mealybugs (Hemiptera: Pseudococcidae) based on integrated molecular and morphological data. Systematic Entomology, Vol.33, 51-71, 2008.

[12] M.B. Kaydan, F. Kozár, Ch. Hodgson. A review of the phylogeny of Palaearctic mealybugs (Hemiptera: Coccomorpha: Pseudococcidae). Arthropod systematics \& phylogeny, Vol.73, No.1, 175-195, 2015.

[13] T. Kondo, P.J. Gullan and D.J. Williams. Coccidology. The study of scale insects (Hemiptera: Sternorrhyncha: Coccoidea). Revista Corpoica - Ciencia y Tecnología Agropecuaria, Vol.9, No.2, 55-61, 2008.

[14] T. Malausa, A. Fenis, S. Warot, J.F. Germain, N. Ris, E. Prado, M. Botton, F. Vanlerberghe-Masutti, R. Sforza, C. Cruaud, A. Couloux, and P. Kreiter. DNA markers to disentangle complexes of cryptic taxa in mealybugs (Hemiptera: Pseudococcidae). Journal of Applied Entomology, Vol.135, 142-155, 2011.

[15] M. Mani, S. Joshi, M. Kalyanasundaram, C. Shivaraju, A. Krishnamoorthy, R. Asokan and K.B. Rebijith. A New Invasive Jack Beardsley Mealybug, Pseudococcus jackbeardsleyi (Hemiptera: Pseudococcidae) on Papaya in India. Florida Entomologist, Vol. 96, No.1, 242-245, 2013.

[16] D.R. Miller, A. Rung and G. Parikh. Scale Insects, edition 2, a tool for the identification of potential pest scales at U.S.A. ports-of-entry (Hemiptera, Sternorrhyncha, Coccoidea). ZooKeys 431: 61-78, 2014.

[17] ScaleNet. Scale Insects: Identification tools, images, and diagnostic information for species of quarantine significance.
Systematic Entomology Laboratory, USDA-ARS. [23 Nov 2011]. Online available from: http://www.sel.barc.usda.gov/scalekeys/ScaleInsectsHome/S caleInsectsHome.html

[18] M.G. Murray and W.F. Thompson. Rapid isolation of high molecular weight plant DNA. Nucleid Acid Reserch, Vol.8, No.19, 4321-4325, 1985.

[19] NCBI. National Center for Biotechnology Information. Rockville Pike, Bethesda, USA. Research. Pseudococcus jackbeardsleyi. [01 Jan 2016]. Online available from: http://www.ncbi.nlm.nih.gov

[20] P.W. N'Guessan, G.W. Watson, J.K. Brown and F.K. N'Guessan. First record of Pseudococcus jackbeardsleyi (Hemiptera: Pseudococcidae) from Africa, Côte D'ivoire. Florida Entomologist, Vol.97, No.4, 1690-1693, 2014.

[21] M. Palma-Jiménez and M. Blanco-Meneses. Acondicionamiento de la cochinilla harinosa (Hemiptera: Pseudococcidae) por Microscopía Electrónica de Barrido. Agronomía Mesoamericana, Vol.26, No.2, 355-364, 2015.

[22] M. Palma-Jiménez and M. Blanco-Meneses. First study about morphological and molecular identification, Pseudococcus elisae in Costa Rica. In press, 2016.

[23] F. Sanger, S. Nicklen and A.R. Coulson. DNA sequencing with chain-terminating inhibitors. Proceedings of the National Academy of Sciences Vol.74, 5463-5467, 1997.

[24] A.N. Shylesha. Host range of invasive Jack Beardsley mealybug, Pseudococcus jackbeardsleyi Gimple and Miller in Karnataka. Plant Management in Horticulture Ecosystem, Vol.19, No.1, 106-107, 2013.

[25] P. Soysouvanh, S. Soo-Jung, and H. Ki-Jeong. Faunistic Study of the Family Pseudococcidae (Hemiptera) from Cambodia and Laos. Korean Journal of Applied Entomology, Vol.54, No.3, 199-209, 2015.

[26] K. Tamura, D. Peterson, N. Peterson, G. Stecher, M. Nei and S. Kumar. MEGA5: Molecular Evolutionary Genetics Analysis using Maximum Likelihood, software version 5.0, 2011.

[27] M.L. Thao, P.J. Gullan, P, Baumann. Secondary $(\gamma$-Proteobacteria) endosymbionts infect the primary ( $\beta$-proteobacteria) endosymbionts of mealybugs multiple times and coevolve with their hosts. Applied Environment Microbiology, Vol.68, No.7, 3190-3197. 2002.

[28] J.D. Thompson, D.G. Higgins, and T.J. Gibson. Clustal W: improving the sensitivity of progressive multiple sequence alignment through sequence weighting, positions-specific gap penalties and weight matrix choice. Nucleic Acids Research, Vol.22, 4673-4680, 1994.

[29] D.J. Williams and M. Granara de Willink. Mealybugs of Central and South America. 1 ed. CAB International, Wallingford. 1992. 